\title{
Resistencia a los sulfatos del cemento portland normal con ceniza volante
}

\author{
Sulfate resistance of ordinary \\ portland cement with fly ash
}

\section{RESUMEN}

La ceniza volante de bajo contenido de oxido de calcio ha demostrado ser una efectiva puzolana para mejorar la resistencia a los sulfatos del cemento portland normal (CPN). En el presente trabajo se estudian los efectos físico-químicos que produce esta puzolana en el mortero expuesto al ataque de sulfatos. Se analizan los efectos de dilución y dispersión utilizando mezclas de cemento con una adición mineral inactiva. Los cambios mineralógicos del mortero se estudian con difracción de rayos $X(D R X)$ y la ayuda del microscopio electrónico.

Los resultados indican que la ceniza volante retarda el fenómeno de fisuración del mortero debido a la menor cantidad de compuestos inestables en ambiente con sulfatos, el mayor espacio disponible para albergar a los compuestos expansivos y la disminución del $\mathrm{CH}$ presente en la mezcla.

\author{
SUMMARY \\ Low calcium fly ash has demostred to be an effective \\ pozzolan to improve sulfate resistance of ordinary portland \\ cement (type 1). In this paper, physico-chemical effects that \\ produce this pozzolan in the mortar exposed to sulfate \\ attack are studied. Dilution and dispersion affects are \\ analysed using mixes of cement with an inert mineral \\ admixture. Mineralogical changes of mortar are studied \\ using $X$-ray diffraction and the help of scanning electron \\ microscope.
}

The results show that fly ash delays mortar cracking phenomenon due to less content of unstable compounds in sulfate enviroment, greater available space to be occupied by expansive compounds and less $\mathrm{CH}$ present in the mortars.

\section{PALABRAS CLAVE:}

Ceniza volante. Resistencia a los sulfatos. Resistencia a flexión. Mortero (material). Análisis por DRX.

\section{INTRODUCCION}

Un estudio anterior [1] ha demostrado que la ceniza volante de bajo contenido de óxido de calcio es una adición mineral efectiva para mejorar la resistencia a los sulfatos del cemento portland normal (CPN). El método de evaluación empleado fue el ensayo de Koch \& Steinegger. Este mejoramiento de la resistencia a los sulfatos es atribuido a la acción simultánea de varios factores:

\section{KEY WORDS:}

Fly ash, sulfate resistance, flexural strength, $X$-ray analysis, mortars (material).

\section{INTRODUCTION}

A previous paper has demonstred that low calcium fly ash is an effectives mineral admixture to improve sulfate resistance of ordinary portland cement (type $1-C P N$ ). Evaluation test employed was Koch \& Steinegger method. The improvement of sulfate resistance is attributed to simultaneous action of several factors:

\footnotetext{
(^) CONICET-LEMIT

(**) CIC-LEMIT.

Calle 52 entre 121 y 122.1900 . La Plata. ARGENTINA.
} 
... a mavor imoemeablidad cel mortero robio a retriamiento de la sotructura de noros provocado oor los productos de la Gowin puzolanioa la y la consecuente rediccion de la velocidad de difusion de 03 ionesagesivos en la mairizl3!

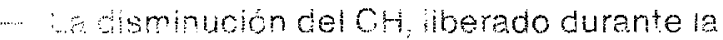
Giracacion dos silcatos de caicio te comento, or combinación con la ceniza $\therefore, \cdots$

- Pmbien se ha sugerido que en los comentos portrand con aciciones existen Crichones desiavorables para la crmación de etringira $[3$ ]

-. Leniza volante produce un efecto de cheprsión de los granos de cemento al actuar como "filler", aumentando el grado ce hidratación del cemento $[4]$.

- Menta i5! ha sugerido que la adición de ina puzolana a un cemento con alto contenico de $\mathrm{C}_{3} \mathrm{~A}$ (Tipo i 6 lii) produce una mejora de la resistencia a los sulfatos por la reducción del $\mathrm{C}_{3} A$ (efecto de dilución).

En el presente trabajo, se evalúan los distintos efectos que produce la incorporación de ceniza volante y se discute su contribución al aumento de ia resistencia química del mortero con CPN.

\section{DETALLES EXPERIMENTALES}

La composición del cemento utilizado fue: $\mathrm{C}_{3}=37.2 \%, \mathrm{C}_{2} \mathrm{~S}=32.6 \%, \mathrm{C}_{3} \mathrm{~A}=7.7 \%$ $y_{4} \mathrm{AF}=12.8 \%$. La ceniza volante (Clase $\mathrm{F}$ según ASTM C-618) se incorporó con tres finuras $\left(280,420\right.$ y $480 \mathrm{~m}^{2} / \mathrm{kg}-8$ laine- $)$. Los reemplazos estudiados fueron del 20 y $30 \%$ en peso de cemento por ceniza. Los detalles completos del cemento y las cenizas volantes, y los resultados de la aplicación del ensayo de Koch \& Steinegger, fueron desarrollados ampliamente en el trabajo anterior. El estudio que se presenta se realizó sobre los morteros conteniendo CPN y ceniza de $420 \mathrm{~m}^{2} / \mathrm{kg}$ de superficie específica (CV2). Para corroborar las conclusiones obtenidas sobre esta serie fueron realizadas determinaciones complementarias sobre los morteros conteniendo las otras cenizas.

Los mecanismos físicos por los cuales la ceniza volante contribuye al aumento de la resistencia quimica (efecto de dispersión y de dilución) fueron estudiados utilizando mezclas de cemento con una adición mineral inerte. Fueron utilizados reemplazos del 20 y $30 \%$ en peso de cemento por cuarzo finamente molido
- Less mortar permeability owed to coreusize reinement produced by pozzolanic ieaction [2] and consequelly a decrease of ditusion velocity of egressives ions 13 i

-.. he remolial of $\mathrm{CH}$, formed during cement calcium silicates hydratalion. oy combination with Hy ash 12.31

.... ithas been suggested that in pozzolanic cements exist uniavorable conditions to obringite formation 3 .

- Fy ash produces a dispersion effect of cement grains and hydratation degree of cement increases.

- Mehta [5] has suggested that addition of a pozzolan to a high-C A portiand cement (type / or lil) improves suifate resistance by $\mathrm{O}_{3} \mathrm{~A}$ reduction (ailution effect).

In this paper, several effects that produces fly ash addition are evaluated and their contribution to chemical resistance of mortar with CPN cement are discussed.

\section{EXPERIMENTAL DETAILS}

Mineralogical composition of CPN cement was: $\mathrm{C}_{3} \mathrm{~S}=37.2 \%, \mathrm{C}_{2} \mathrm{~S}=32.6 \%, \mathrm{C}_{3} \mathrm{~A}=7.7 \%$ and $\mathrm{C}_{4} \mathrm{AF}=12.8 \%$. Fly ash (Class $F-$ ASTM C618) was incorporated with three fineness $\left(280,420\right.$ and $480 \mathrm{~m}^{2} / \mathrm{kg}$ - Blaine-). Replace studied were 20 and $30 \%$ of cement weigth by fly ash. Full details of cement and fly ashes, and results of Koch \& Steinegger test were developed in published paper [1]. The present study was realized in mortars with CPN and fly ash with $420 \mathrm{~m}^{2} / \mathrm{kg}$ of specific surface (CV2). To corroborate the conclusions obtained, complementary determinations were realized on mortars with other fly ashes.

Physical mechanics that produces fly ash to improve chemical resistance idispersion and dilution effects) were studied using mixes of cement and an inert mineral admixture. Replacement of 20 and $30 \%$ in cement weigth by ground quartz (specific surface $420 \mathrm{~m}^{2} / \mathrm{kg}$ - Blaine-) were used. Result obtained of Koch 
$\left(420 \mathrm{~m}^{2} / \mathrm{kg}\right.$ de superficie específica

- Blaine-). Los resultados obtenidos de la aplicación del ensayo de Koch \& Steinegger se encuentran en la Tabla l.

\& Steinegger test are showed in Table 1.

TABLA I (TABLE 1)

Resultados de los morteros CPN/cuarzo evaluados según Koch \& Steinegger (Results of CPN/quartz mortars evaluate according to Koch \& Steinegger test)

\begin{tabular}{|c|c|c|c|c|c|}
\hline \multirow{2}{*}{$\begin{array}{c}\text { Cuarzo } \\
\text { Quartz } \\
{[\%]}\end{array}$} & \multirow{2}{*}{$(*)$} & \multicolumn{4}{|c|}{ EDAD [Dias] / AGE [Days] } \\
\hline & & $21+0$ & $21+14$ & $21+28$ & $21+56$ \\
\hline \multirow{3}{*}{0} & $\mathrm{H}$ & 7.18 & 7.10 & 7.13 & 7.21 \\
\hline & $N \bar{S}$ & & 6.67 & 5.28 & 2.16 \\
\hline & $\mathrm{R}$ & 1.00 & 0.94 & 0.74 & 0.30 \\
\hline \multirow{3}{*}{20} & $\mathrm{H}$ & 5.11 & 5.45 & 5.71 & 5.82 \\
\hline & $N \bar{S}$ & & 6.10 & 4.95 & 3.40 \\
\hline & $\mathrm{R}$ & 1.00 & 1.12 & 0.87 & 0.58 \\
\hline \multirow{3}{*}{30} & $H$ & 4.12 & 5.46 & 5.50 & 5.54 \\
\hline & $N \bar{S}$ & & 5.33 & 4.83 & 2.99 \\
\hline & $\mathrm{R}$ & 1.00 & 0.98 & 0.87 & 0.54 \\
\hline
\end{tabular}

(*) $H_{-}=$Curado en agua. (Cured in water).

$N \bar{S}$-... Curado en sulfato. (Cured in sultate)

$\mathrm{A}=$ Factor de corrosión. (Corrosion factor).

Los cambios mineralógicos del mortero fueron estudiados por Difracción por Rayos X (DRX) y el auxilio del microscopio electrónico (SEM) equipado con un analizador de compuestos por energía dispersada por rayos $X$ (EDAX). $E$ material analizado por DRX fue obtenido de la siguiente manera: Una vez ensayadas a flexión las probetas, se escogió entre la serie aquella cuya resistencia es más próxima a la media. Se secó a $40^{\circ} \mathrm{C}$ hasta peso constante, se enfrió en desecador y se molió la probeta hasta que el material pasase a través del tamiz $75 \mu \mathrm{m}(\mathrm{N} .200)$. Las observaciones al microscopio electrónico se efectuarón sobre el extremo de la misma probeta. Las figuras 1 y 2 muestran los diagramas de DR火 obtenidos para los morteros constituidos por CPN y CPN/30CV2 a distintas edades de curado en agua y de curado en disolución de sulfato de sodio.

La porosidad del mortero fue determinada según el procedimiento propuesto por la norma BS 1881 - Parte 6. Los prismas se secan hasta peso constante a $105^{\circ} \mathrm{C}$ y luego se enfrian en desecador. Seguidamente se sumergen en tetracloruro de carbono en un recipiente al vacio. El vacio se aplica hasta que las burbujas de aire cesen de emerger del prisma. Se determina su masa y luego se
Mineralogical changes of mortars were studied by X-ray diffraction (XRD) and the help of scanning electron microscope (SEM) equiped with an energy dipersion analizer $X$-ray (EDAX). Material analized by XRD was obtained in following way: Once prisms were tested, it was selected a prism with mean flexural strength. It was dried at $40^{\circ} \mathrm{C}$ until constant weigth and it was ground until material pass trougth sieve $75 \mu m\left(N^{\circ} 200\right)$. SEM observations were realized on the extreme of the same prism. Figures 1 and 2 show $X$-ray diffractograms obtained for mortars with CPN and CPN/30CV2 cement at different age of cured in water and sodium sulfate solution.

Mortar porosity was determinated according to BS 1881 - Part 6 test. The prism was dried to constant weigth at $105^{\circ} \mathrm{C}$, cooled in desiccator and then immersed in vacuumflask contained carbon tetrachloridre. Vacuum was applied until air bubbles ceased to emmerge from prisms surface. It mass was determinated and the carbon tetrachloridre was evaporated at $105^{\circ} \mathrm{C}$. Finally, the mass of dry prism was 
evapora el $\mathrm{CCl}_{4}$ a $105^{\circ} \mathrm{C}$. Finalmente, se determina la masa del prisma seco y con estos valores la porosidad:

determinated. Capillary porosity was calculated as:

$$
\underset{(\text { Porositi })}{\text { Porosidad }}(\%)=\frac{[P s-P d]}{1.6 \times P d} \times 100
$$

donde: $P S=$ masa del prisma saturado; $\mathrm{Pd}=$ masa del prisma seco; $1.6=$ densidad del $\mathrm{CCl}_{4}$.

La Tabla II muestra la evolución de la porosidad de los morteros conteniendo CPN, CPN/20CV2 y CPN/30CV2.

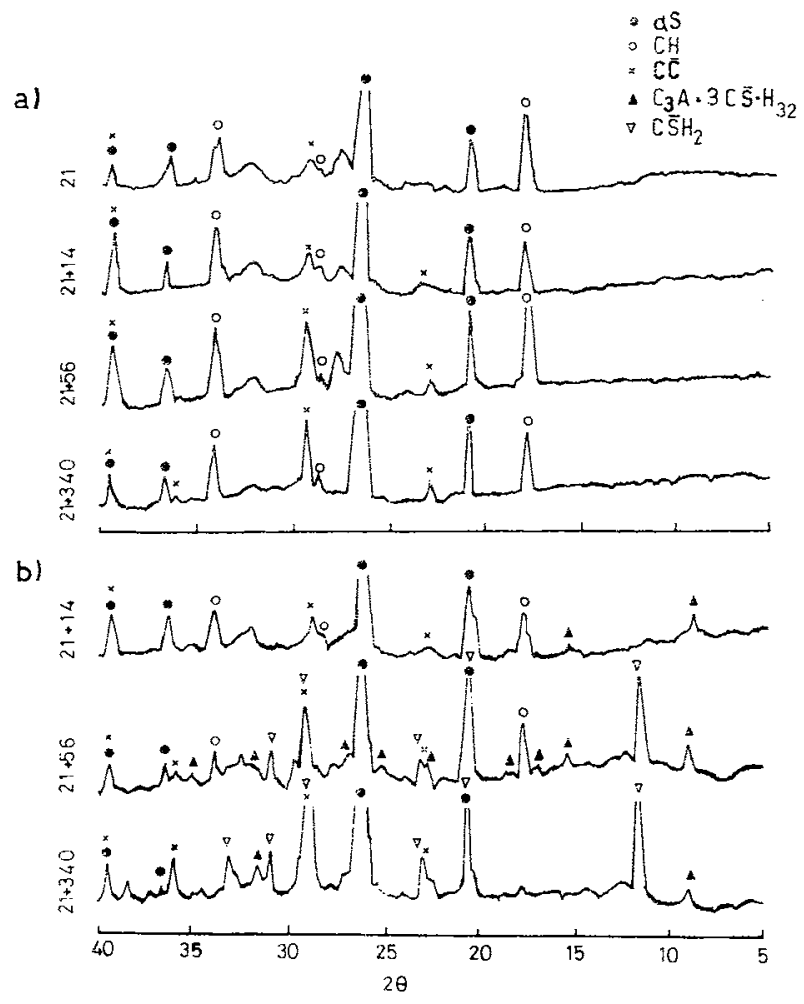

Fig. 1.-Diagramas de DRX del mortero con cemento portland normal. a) Curado en agua. b) Curado en disolución de sulfato de sodio.

Fig. 1.-X-ray diffractograms of CPN mortar. a) Cured in water. b) Cured in sodium sulfate solution. where: Ws is satured prism weigth and Wd is dry prism weigth, Capillary porosity of CPN, CPN/20CV2 and CPN/30CV2 mortars are showed in Table $1 /$.

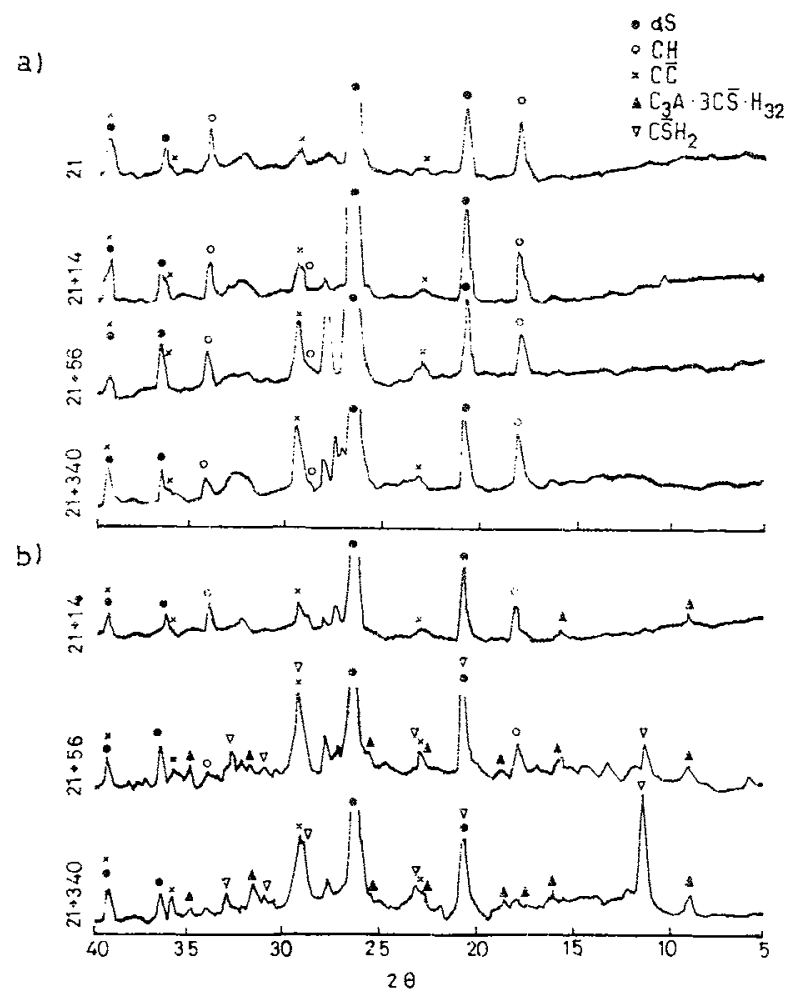

Fig. 2.-Diagramas de DRX del mortero constituido por CPN/30CV2. a) Curado en agua. b) Curado en disolución de sulfato de sodio.

Fig. 2.-X-ray diffractograms of CPN/30CV2 mortar. a) $\mathrm{Cu}$ red in water. b) Cured in sodium sulfate solution.

TABLA II (TABLE II)

Porosidad capilar de los prismas de mortero (\%)

[Capillar porosity of mortars prisms (\%)]

\begin{tabular}{|c|c|c|c|c|c|c|}
\hline CEMENTO & \multicolumn{2}{|c|}{ CPN } & \multicolumn{2}{|c|}{$\mathrm{CPN}+20 \mathrm{CV} 2$} & \multicolumn{2}{|c|}{$\mathrm{CPN}+30 \mathrm{CV} 2$} \\
\hline \multirow{2}{*}{$\begin{array}{c}\text { EDAD/AGE } \\
\text { [Dias/ } \\
\text { Days] }\end{array}$} & \multicolumn{2}{|c|}{ Curado en / Cured in } & \multicolumn{2}{|c|}{ Curado en / Cured in } & \multicolumn{2}{|c|}{ Curado en / Cured in } \\
\hline & $\mathbf{H}$ & $\mathbf{N S}$ & H & NS & H & $\mathbf{N} \overline{\mathbf{S}}$ \\
\hline $21+0$ & 6.5 & - & 7.9 & - & 7.6 & - \\
\hline $21+14$ & 6.5 & 9.2 & 7.9 & 7.5 & 7.7 & 7.4 \\
\hline $21+56$ & 5.8 & 9.3 & 7.7 & 8.2 & 8.0 & 8.1 \\
\hline
\end{tabular}

(*) $\mathrm{H}_{-}=$Curado en agua. (Cured in water).

$N \bar{S}=$ Curado en sulfato. (Cured in sulfate) 


\section{DISCUSION DE LOS RESULTADOS}

\subsection{Efectos de dilución y de dispersión}

La figura 3 muestra la variación del factor de corrosión (R) del CPN y de los morteros conteniendo 20 y $30 \%$ de reemplazo en peso de CPN por cuarzo molido o ceniza volante.

Las mezclas cemento-cuarzo presentan un factor de corrosión mayor al correspondiente al cemento puro para todas las edades, a pesar de que la relación agua/cemento se incremente a 0.70 y 0.87 para los morteros con 20 y $30 \%$ de cuarzo respectivamente. La diferencia se acentúa a los $21+56$ días. Este mejoramiento indica que la disminución relativa del $\mathrm{C}_{3} \mathrm{~A}$ en los morteros con cuarzo o ceniza volante $\left(6.2 \%\right.$ y $5.4 \%$ de $\mathrm{C}_{3} \mathrm{~A}$ calculado para las mezclas con 20 y $30 \%$ de reemplazo, respectivamente) desacelera el proceso corrosivo. También existe una menor cantidad de $\mathrm{CH}$ presente en el mortero debido a la disminución relativa de los silicatos. Además, debe tenerse en cuenta que el cuarzo actúa como dispersante de las partículas de cemento permitiendo una mejor hidratación de sus granos. El comportamiento de la mezclas que contienen 20 y $30 \%$ de cuarzo es similar. De todas maneras, el efecto de dilución que produce la incorporación de ceniza volante por sí sólo no es suficiente para obtener un comportamiento satisfactorio del cemento frente al ataque de sulfatos (Factor $R$ mayor a 0.7 a los $21+56$ días).

\section{DISCUSSION OF RESULTS}

\subsection{Dilution and dispersion effects}

Figure 3 shows Corrosion Factor (R-Factor) variation of mortars with CPN cement and mortars with replace of 20 and $30 \%$ of cement weigth by ground quartz or fly ash. Quartz CPN mortars present a corrosion factor higher than neat cement at all curing age. In spite of that water/cement ratio is 0.70 and 0.87 for mortar with 20 and $30 \%$ of quartz, respectively. This improvement of sulfate resistance indicates that relative diminution of $C_{3} A$ in mortars with quartz or fly ash (calculated $C_{3} A$ content 6.2 and $5.4 \%$ for mixes with replace of 20 and $30 \%$, respectively) decelerates corrosive process. Less $\mathrm{CH}$ content is present in mortar owed to relative diminution of calcium silicates. Besides, ground quartz disperses cement grains and permits a better hydratation of them. Behavior of mortar with 20 and $30 \%$ of quartz is similar.

At any rate, dilution effect that produce fly ash addition isn't enough to obtained a satisfactory behaviour of cement (corrosion factor higher than 0.7 at $21+56$ days).

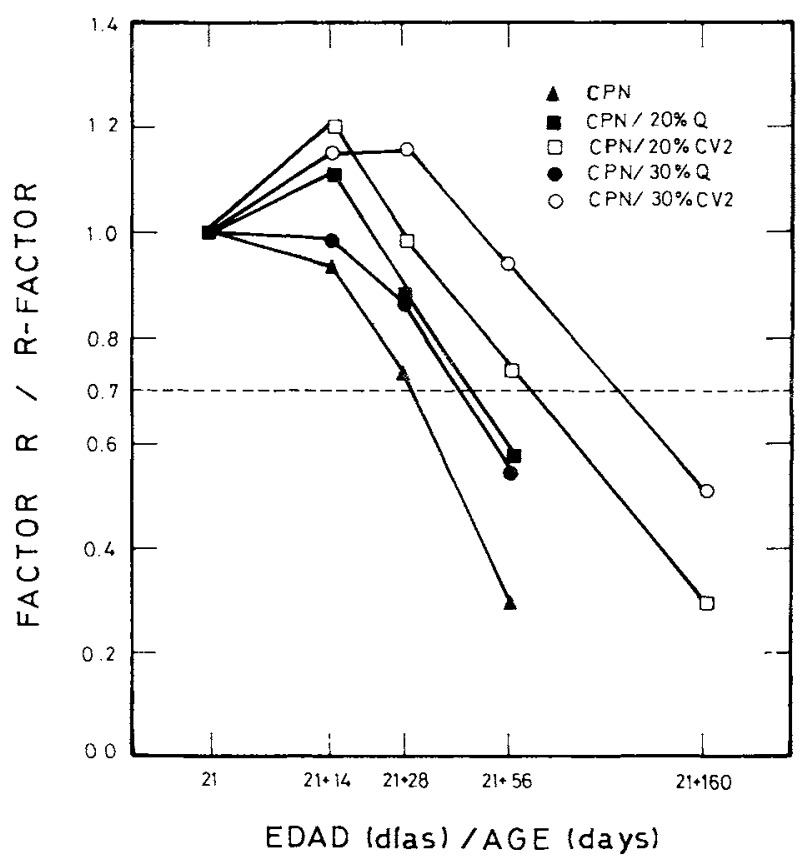

Fig. 3.-Variación del factor de corrosión de los morteros con la adición mineral inerte y ceniza volante.
Fig. 3.-Corrosion factor variation of mortars with inert mineral admixture and tly ash. 


\subsection{Analisis de DRX, SEM y porosidad}

Antes de la exposición, la resistencia a los sulfatos de los cementos en estudio está determinada - en gran medida - por la presencia de compuestos inestables en el ambiente agresivo. Al "debut" del ataque (21 días) no se detectaron monsulfoaluminato $\left(\mathrm{C}_{4} \mathrm{ASH}_{12}\right)$ o hidrogranates $\left(\mathrm{C}_{4} \mathrm{AH}_{13}\right)$ por medio de DRX para ninguna de las mezclas. La ayuda de SEM ha permitido determinar su presencia (Figura 4). Estos compuestos son los responsables de la futura formación de ettringita. En los morteros CPN/CV se ha observado una baja reacción de la ceniza volante (Figura 5) y una pobre adherencia entre las esferas de ceniza y la matriz. Estas observaciones justifican la menor resistencia inicial a flexotracción y el aumento de la porosidad capilar de estos morteros.

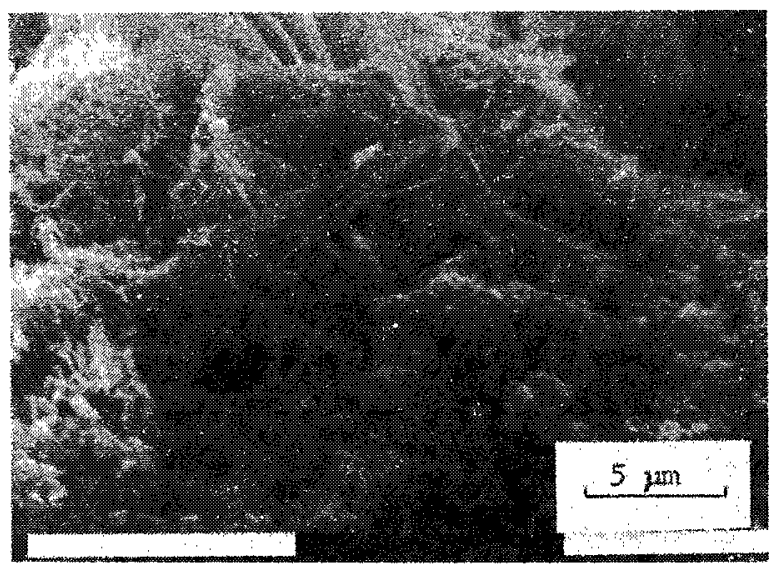

Fig. 4.-Cristales de monosulfoaluminato en el mortero de CPN a los 21 dias de curado en agua.

Fig. 4.-Monosulfoaluminates crystals in CPN mortar at 21 days of cured in water.

A mayores edades, los prismas estacionados en agua presentan un marcado aumento de la carbonatación superficial, debido a la reacción entre el $\mathrm{CH}$ de la pasta y el $\mathrm{CO}_{2}$ disuelto en el agua. El pH del agua de estacionamiento crece de 7-7.2 a los 21 días hasta $10-11$ a los $21+340$ días, rango dentro del cual se produce la precipitación del $\mathrm{CaCO}_{3}$ sobre la superficie de la probeta [6]. Este proceso se detecta en los diagramas de DRX por el crecimiento de los picos correspondiente a calcita $\left(2 \theta=29.5^{\circ}\right)$. Mediante SEM se ha observado que los cristales de $\mathrm{CaCO}_{3}$ tapizan la superficie de la probeta (Figura 6).

En los morteros CPN/CV la variación más importante que se encuentra a medida que crece el tiempo de curado en agua es la disminución del $\mathrm{CH}\left(2 \theta=34.0^{\circ} / 18.0^{\circ}\right)$ debido al progreso de la reacción puzolánica.

\subsection{XRD analysis, SEM and porosity}

Before attack, sulfate resistance of cement in study is determinated - in most way- by presence of unstable compounds in sulfate enviroment. At attack start (21 days), monosulfoaluminates $\left(\mathrm{C}_{4} \mathrm{ASH}_{12}\right)$ and hydrogarnets $\left(\mathrm{C}_{4} A H_{13}\right)$ aren't detected by $X$-ray analysis in any mortars. The help of SEM has permited its detection (Figure 5). This compounds are responsible of future ettringite formacion. In CPN/CV mortars, it was seen a low fly ash reaction an a poor adherence between fly ash and cementitious matrix. This observation gives a justified to lower initial flexural strength and higher capillary porosity of CPN/CV mortars.

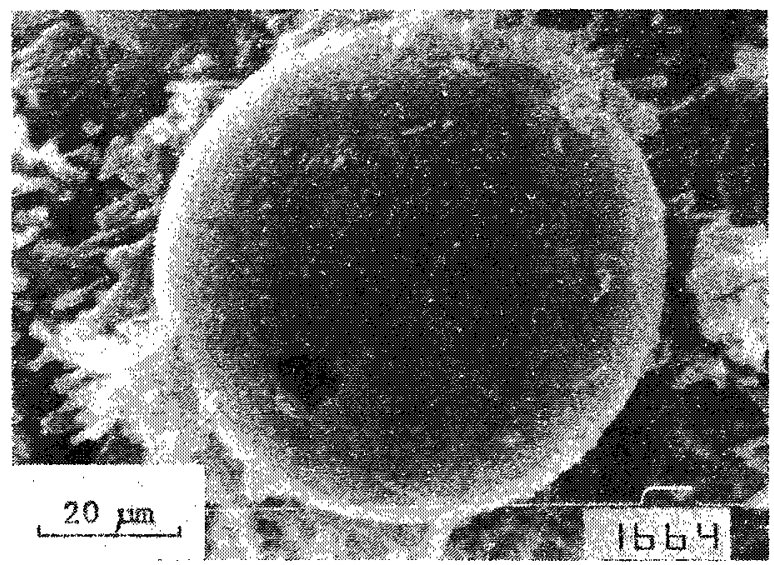

Fig. 5.-Particula de ceniza volante en el mortero con CPN/30CV2 a los 21 días de curado en agua.

Fig. 5. - Fly ash particle in CPN/30CV2 mortar at 21 days of cured in water.

At later age, the prisms strored in water present an increase of surface carbonation owed to reaction between $\mathrm{CH}$ of paste and dissolved $\mathrm{CO}_{2}$ in water. At 21 days $\mathrm{pH}$ of storage water is 7-7.5 and it increases until 1011 at $21+340$ days. For this $\mathrm{pH}$-values, $\mathrm{CaCO}_{3}$ precipites on specimens surface [6]. This process is detected in X-ray diffractograms by growth of pick correspondent to calcite $(2 \theta=$ $29.5^{\circ}$. SEM observation shown that calcite crystals cover prism surface (Figure 6).

In CPN/CV mortars cured in water, the most important variation of mineralogical composition when curing time increases is the diminution of $\mathrm{CH}$ pick $\left(2 \theta=34.0^{\circ}\right)$ due to pozzolanic reaction progress. 
El estudio de los morteros CPN/CV expuestos a la agresión de la disolución de sulfato de sodio muestra al cabo de $21+14$ días el crecimiento de cristales de ettringita y una disminución de la porosidad del mortero. Ambos datos, complementados por las observaciones SEM, permiten afirmar que estos cristales crecen en los poros de las probetas (Figura 7). El aumento de la resistencia a la flexión de los prismas CPN/CV se debe al taponamiento de los poros del mortero. También contribuye, el aumento de la hidratación de los granos de cemento y de ceniza volante. Los iones sulfato degradan el $\mathrm{CH}$ de la matriz cementícea, permitiendo un avance de la hidratación de los silicatos del cemento. A la vez, la hidratación de los silicatos liberan $\mathrm{Ca}^{2+}$ y $(\mathrm{OH})^{-}$, que pasan a la disolución intersticial favoreciendo la reacción de los compuestos ácidos de la ceniza volante.

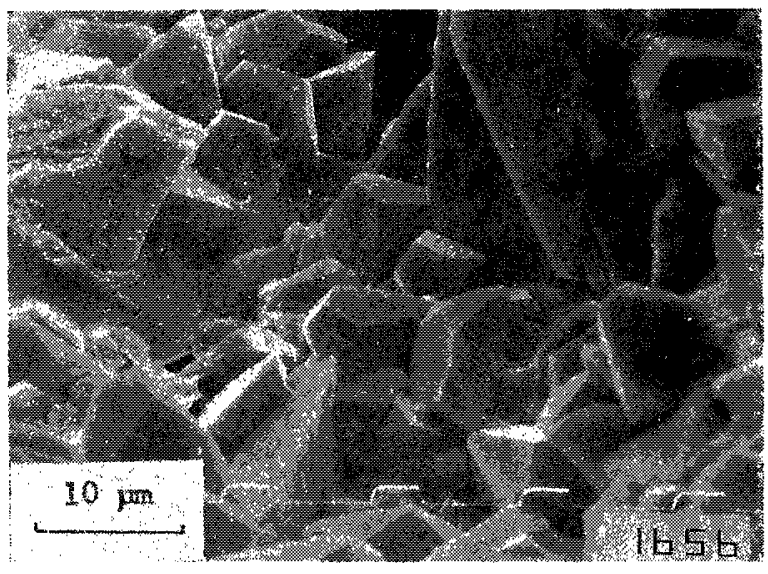

Fig. 6.-Cristales de calcita formados en la superficie de la probeta de CPN/30CV 2 a los $21+56$ dias de curado en agua.

Fig. 6.-Calcite crystals formed on specimen surface of CPN/30CV2 mortar at $21+56$ days of cured in water.

Después de un cierto tiempo de exposición, los cristales de ettringita y yeso exceden el espacio disponible y generan tensiones internas que sobrepasan la resistencia a tracción del material, ocasionando la fisuración. La resistencia mảxima a flexotracción que alcanzan los prismas curados en la disolución de sulfato depende de la constitución del mortero y está relacionada con la resistencia capaz de desarrollar el material (resistencia máxima en agua o resistencia última). En la figura 8 se observa esta relación para los distintos morteros estudiados anteriormente. Se observa que la resistencia máxima en sulfatos (fsm) disminuye con respecto a la resistencia última (fwu) cuando decrece la resistencia a los sulfatos del mortero. Los morteros con CPN/20CV y CPN/30CV alcanzaron
At $21+14$ days, CPN/CV mortars exposed to sodium sulfate aggression show a growth of ettringite crystals and mortar porosity decreases. SEM observation permits tu affirm that ettringite crystals grows in mortar pores (Figure 7).

Flexural strength of CPN/CV mortars increase owed to pore filled. The increase of hydratation of cement and fly ash grains contributes too. Sulfate ions degrade $\mathrm{CH}$ of cementitiuos matrix and permits the progress of calcium silicates hydration. At the same time, calcium silicate hydratation frees $\mathrm{Ca}^{2+}$ and $(\mathrm{OH})$ - that pass to interstitial solution and facilitates the reaction of acid compound of fly ash.

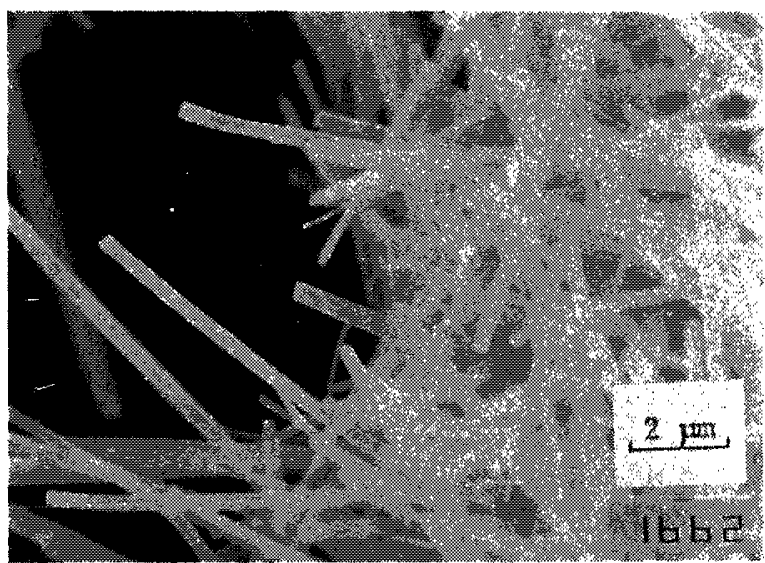

Fig. 7.-Cristales de ettringita formados en los poros del mortero CPN/30CV2 a $21+56$ días de curado en disolución de sulfato de sodio.

Fig. 7.-Ettringite crystals formed in CPN/30CV2 mortat pore at $21+56$ days of cured in sodium sulfate solution.

After some exposition time, ettringite and gypsum crystals exceed available space ano generate internal stress that overcome mortar tensil strength. Then prisms crack. Maximum flexural strength of prisms cured in sulfate solution depends of mortar composition and it's related with own material strength (Final strength or maximun flexural strength in water at $21+340$ days). Figure 8 shows this relation for previously studied mortars. It can be seen that maximum flexural trength in sulfate decrease with respect to final strength when sulfate resistance of mortar decrease. $C P N / 20 \mathrm{CV}$ and $\mathrm{CPN} / 30 \mathrm{CV}$ mortars attaint to 80 and $90 \%$ of final strength, respectively. Or: the other hand, mortars with sulfate resistant cement and fly ash overcome this value. This behaviour indicates that internal stresses generated by expansive compounds in $\mathrm{CPN} / \mathrm{CV}$ 


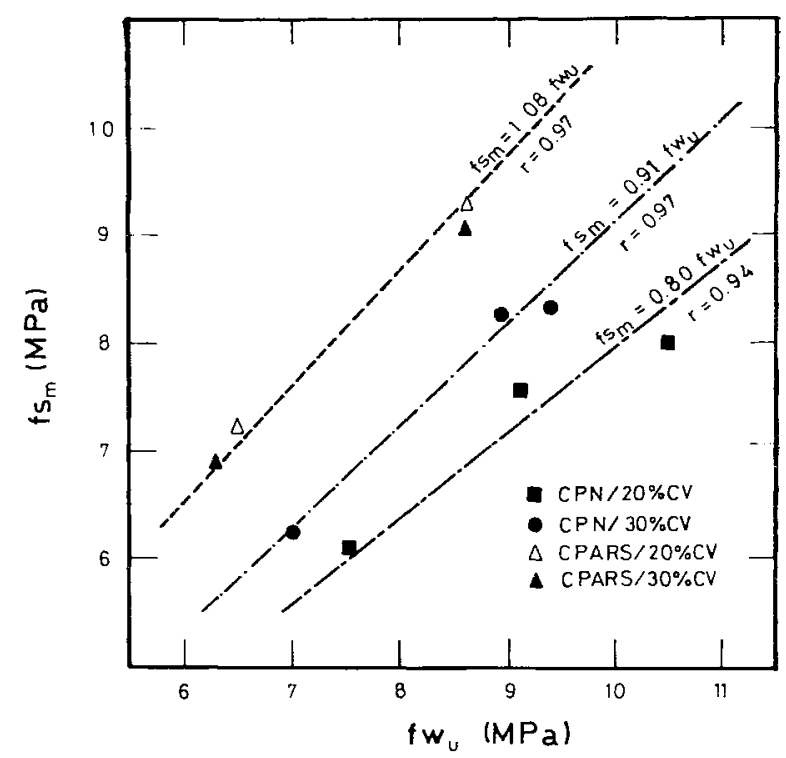

aproximadamente el $80 \%$ y $90 \%$ de la resistencia última, mientras que los constituidos por cemento portland resistente a los sulfatos y ceniza volante sobrepasan este valor. Este comportamiento indica que las tensiones internas generadas por los compuestos formados supera a la resistencia del material antes que éste desarrolle su resistencia última. La fisuración del mortero determina la caida de la resistencia a flexión. El tiempo de fisuración puede ser obtenido como la abscisa del máximo de la curva de evolución de la resistencia a flexión en forma analítica utilizando un ajuste por mínimos cuadrados. Este valor resulta ser un excelente indicador de la resistencia a los sulfatos del material [7]. Para los morteros estudiados fue de 21,37 a 42 y 51 a 57 días para el CPN, CPN/20CV y CPN/30CV respectivamente.

La mayor superficie expuesta a la agresión, producto de la fisuración, determina un aumento de la velocidad de corrosión. A partir de este momento adquiere mayor importancia la corrosión ácida - formación de yeso-:
Fig. 8.-Relación entre la resistencia final en agua ( $\mathrm{fwu}$ ) y la resistencia máxima en sulfato (fsm).

Fig. 8.-Relation between final strength in water (fwu) and maximum strength in sulfate (fsm). mortars exceed material strength before it develops its final strength.

Mortar-cracking determines flexural strength diminution. Cracking-time can be obtained with analitical method as $x$-value of maximum in flexural strength vs. time curve using a minimun square adjustement. It's an excelent indicator of mortar sulfate resistance [7]. Cracking-time was 21, 37-42 and 51-57 days for CPN, CPN/20CV and CPN/30CV mortars, respectively.

$$
\mathrm{CH}+\mathrm{NS}+2 \mathrm{H} \longrightarrow \mathrm{C}_{\bar{S}} \mathrm{H}_{2}+2 \mathrm{NH}
$$

En los morteros CPN/CV esta reacción es demorada. A los $21+56$ días se observa una mayor cantidad de yeso $\left(2 \theta=11.7^{\circ}\right)$ en el cemento portland que en los CPN/CV (Ver figuras 1 y 2) y como consecuencia disminuye el pico de $\mathrm{CH}\left(2 \theta=34.0^{\circ}\right)$. También se observa un incremento de la porosidad. El retraso del ataque ácido al mortero con CPN/CV es causado porque: el progreso de la reacción puzolánica disminuye el $\mathrm{CH}$ de la
In CPN/CV mortars, this reaction is delayed. At $21+56$ days, it can be seen freater gypsum formation $\left(2 \theta=11.7^{\circ}\right)$ in CPN mortar than CPN/CV mortars (see Figures 1 and 2). Consecuentely $\mathrm{CH}$-pick $\left(2 \theta=34^{\circ}\right)$ decrease and capillary porosity increases. Diminution of acid attack to CPN/CV mortars is caused because: $\mathrm{CH}$ is removed by pozzolanic reaction and crack-phenomenon is delayed due to less ettringite formation and greater mortar 


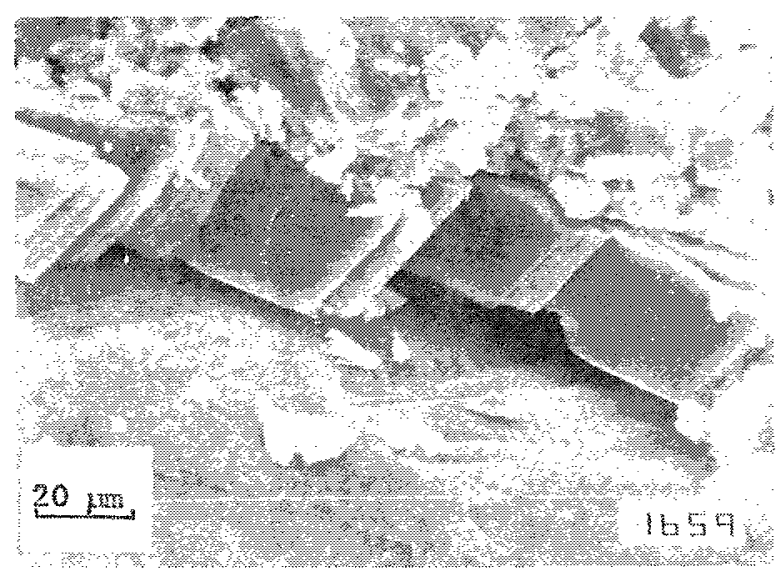

Fig. 9.- Yeso formado en la zona de transición pastaagregado del mortero CPN a los $2 ?+56$ dias.

Fig. 9.-Gypsum crystal in transition paste-aggregate zone of CPN mortar at $27+56$ days.

pasta y el proceso de fisuración se encuentra retrasado debido a la disminución de la formación de ettringita y la mayor capacidad del mortero de albergar a los compuestos expansivos formados. La formación de yeso tiene lugar en los poros y en la zona de transición pasta-agregado (Figura 9).

Al cabo de un año $(21+340$ dias $)$ de exposición, el $\mathrm{CH}$ se ha transformado totalmente en yeso. El CH no se detecta por medio de DRX. El yeso se observa cristalizado en grandes bloques ubicado preferentemente en las fisuras (Figura 10). También se le detecta en forma de prismas.

El mayor deterioro que sufren los morteros con CPN/2OCV respecto a los CPN/30CV debe ser atribuido a una mayor cantidad de yeso. La figura 11 muestra los diagramas de DRX a $21+160$ días para todos los cementos con ceniza volante. El proceso de carbonatación superficial también tiene iugar en los prismas estacionados en disolución de sulfato de sodio.

Fig. 11.-DRX de los morteros conteniendo ceniza volan. te a los $21+160$ dias de curado en solución agresiva.

Fig. 11.-X-ray diffractograms of mortars contained tly ash at $21+160$ days of cured in aggressive solution.

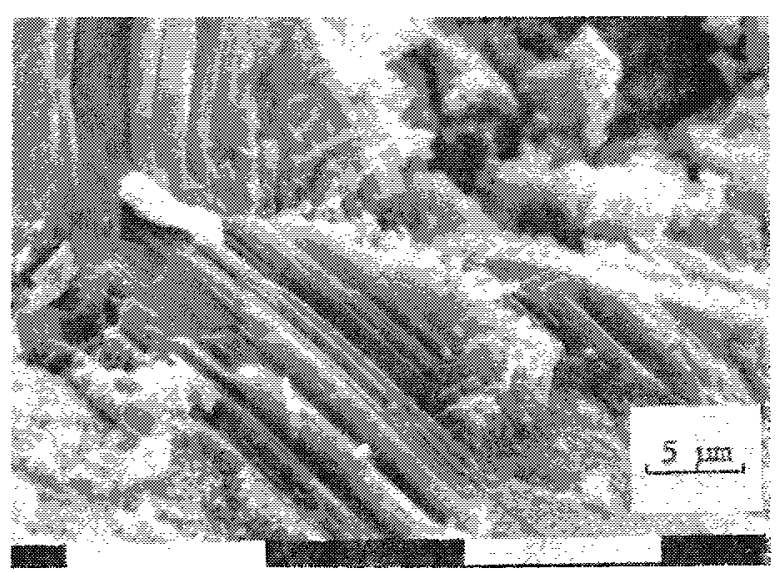

Fig. 10.-Bloque de yeso en la muestra de CPN a los $21+340$ días.

Fig. 10.-Gypsum block in CPN moriar a! $21+340$ days.

capacity to be occopied by expansive compounds. Gypsum formation takes place in pores and transition paste-aggregate zone (Figure 8).

After one year $(21+340$ days $), \mathrm{CH}$ is transformed totally in gypsum. It cann't be detected by XRD. Gypsum is crystalized in block and localized in cracks preferentially (Figure 10). Gypsum prisms can be seen ir CPN mortar, too.

Greater degradation of CPN/20CV mortars than CPN/30CV mortars is attributed to a greater formation of gypsum. Figure 11 shows $X$-ray diffractograms for all CPN/CV mortars at $2\}+160$ days. Surface carbonation takes place in prisms cured in sulfate solution, too.

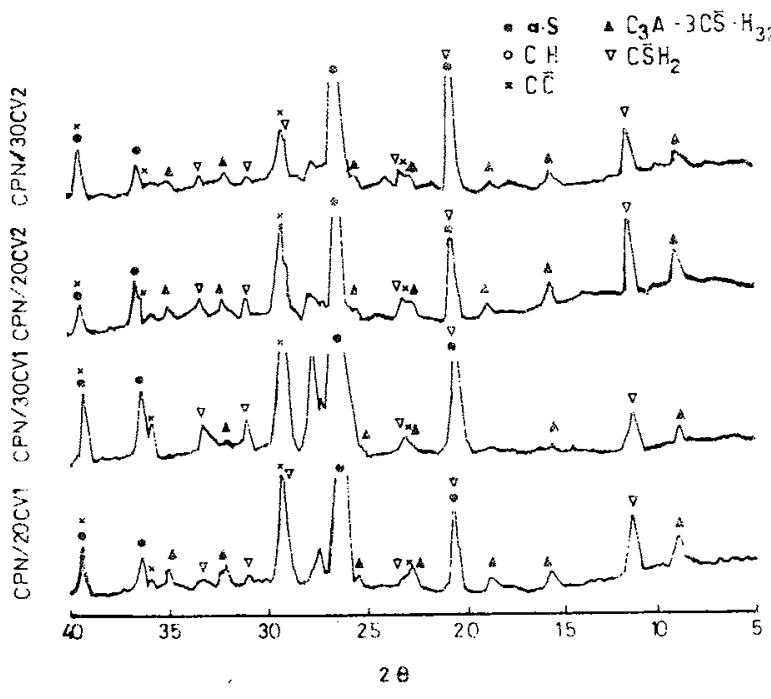




\section{CONCLUSIONES}

Los resultados del presente estudio permiten realizar las siguientes consideraciones acerca de las causas del incremento de la resistencia a los sulfatos de las mezclas de cemento portland normal con ceniza volante:

a) En las primeras edades de exposición, el efecto de dilución (menor cantidad de $\mathrm{C}_{3} \mathrm{~A}$ en el mortero) disminuye la formación de ettringita que causa la fisuración. La velocidad de generación de tensiones internas es menor a medida que disminuye el contenido de $\mathrm{C}_{3} \mathrm{~A}$ en el mortero.

b) La distinta naturaleza de los poros y la mayor porosidad de los morteros con ceniza volante y su capacidad de generar nuevos vínculos, permiten albergar a los compuestos expansivos en su seno.

c) La disminución del $\mathrm{CH}$ por el progreso de la reacción puzolánica disminuye y retarda la corrosión de carácter ácido que provocan los sulfatos - formación de yeso-.

\section{CONCLUSIONS}

Results of this research permit to enumerate the following considerations in relation with the improvement of sulfate resistance in CPN/fly ash mortars.

a) At first age of attack, dilution effect (less $\mathrm{C}_{3} A$ content in cement) decreases ettringite formation wich causes mortar-cracking. Rate of internal stresses generation is smaller when $\mathrm{C}_{3}$ A content of cement decreases.

b) Greater porosity of mortar with fly ash and its capacity to generate new bonds permits to lodge an expansive compounds.

c) Removal of $\mathrm{CH}$ by pozzolanic reaction decreases an delays acid corrosion of sulfate solution - gypsum formation-.

\section{BIBLIOGRAFIA}

[1] IRASSAR, E. F. SOTA, J. BATIC, O. R.: "Evaluación de la resistencia a los sulfatos de cementos con ceniza volante". Materiales de Construcción IETCC, V. 38, núm. 212, págs. 21-35, (1988).

[2] MEHTA. P. K.: "Concrete: structure and properties". Prentice Hall, N. Y., pag. 269 (1986).

[3] MASSAZZ,A. F.: "Chemertry of pozzolanic additions and mixed cement". II Cemento 1/1976, pag. 3-38 (1976).

[4] DHIR R. K. et al:: "Contribution of PFA to concrete workability and strength development". Cement and Concrete Research, V. 18, núm. 2, pag. 277-289 (1988).

[5] MEHTA, P. K.: "Effect of fly ash composition in sulfate resistance of cement". ACl Journal, V. 83, pag. 994-1.000 (1986).

[6] SAGRERA J. L.; GASPAR TEBAR D.: "Resistencia química del hormigón ...". Materiales de Construcción IETcc, V. 32, núm. 192, págs. 33-41 (1981).

[7] IRASSAR, E. F.: "Modelo matemático de la resistencia a los sulfatos de cementos con adiciones". Sin publicar. 